\title{
無酸素銅における低変形固相拡散接合
}

\author{
塚本 雅章* 阪 本 諭志* 山本厚之
}

兵庫県立大学大学院工学研究科物質系工学専攻

J. Japan Inst. Metals, Vol. 75, No. 10 (2011), pp. 592-599

(C) 2011 The Japan Institute of Metals

\section{Solid State Diffusion Bonding with Low Deformation on Oxygen Free Copper}

\author{
Masaaki Tsukamoto*, Satoshi Sakamoto* and Atsushi Yamamoto \\ Division of Materials Science and Chemistry, Graduate School of Engineering, University of Hyogo, Hyogo 671-2201
}

\begin{abstract}
Diffusion bonding requires loading relatively high pressures at elevated temperatures in order to advance an adhesion between surfaces. In the case of oxygen free copper, remarkable deformation occurs during the bonding process due to its poor mechanical strength at high temperatures. In the present study, the diffusion bonding of oxygen free copper under low pressures which enable the specimens to minimize deformation was attempted at $1073 \mathrm{~K}$ for $3.6 \mathrm{ks}$ and $7.2 \mathrm{ks}$ with other experimental factors. The process for increasing bonding areas consists of deformation and diffusion mechanisms. It was important to promote the latter because the former gets poorer under the low bonding pressures. Tensile strength of the specimens was increased with decreasing roughness on the bonding surfaces and comparable to that of the base metal in the specimens whose surfaces were polished with an emery paper \# 4000 and buffing. Furthermore, a fracture occurred at not the bonded interface but the base metal when contact between the bonding surfaces was delayed until a temperature was raised up to bonding condition. In the conventional procedure for diffusion bonding, the temperature has been generally raised with contact between the bonding surfaces so that copper oxides at the bonded interface are difficult to be decomposed due to depressed evacuation. The bonding surfaces were maintained as a free surface by the delayed contact procedure, which led to decomposing the copper oxides. Consequently, the tensile strength would be improved by reducing fracture origins. Grain boundary migration across the bonded interface was sufficiently generated only in the specimen prepared with buffing and prolonged for $7.2 \mathrm{ks}$ in bonding time. In contrast, the fracture at the base metal was achieved in the specimens maintaining an original bonded interface. It was suggested that the grain boundary migration was not necessary to acquire superior joints.
\end{abstract}

(Received April 15, 2011; Accepted June 24, 2011)

Keywords: oxygen free copper, diffusion bonding, low deformation, surface roughness, contact timing, grain boundary migration

\section{1. 緒言}

冷却を要する装置や機器には, 優れた熱伝導性から無酸素 銅が構造材として使用されることが多い。また，内部流路を 形成する場合は接合技術が必要となり, さらに, 寸法精度の 維持や接合部における熱伝達損失, 電触の抑制など, 採用す る工法にも制約が生じる。これには拡散接合が最も適する が，高温での機械的強度が著しく低下する無酸素銅に対して は, 従来の高荷重加圧方式では対象物の原形を留めた上での 接合が困難である1). 変形抑制という点では, 高温高圧ガス を媒体として被対象物を等方的に加圧する HIP (Hot Isostatic Press)法が有効とされているが, 中空構造を持つ場合に は施工できないという大きな欠点がある.

拡散接合における変形抑制には, 低温化もしくは低圧化が 要求される. 温度は, アレニウスの式で依存性が示されるよ うに拡散に対する影響が大きい。両者を比較した場合, 接合 状態への懸念が少ないのは压力であると考えられる.しかし ながら, 圧力も接合機構を促進させる重要因子の一つであ

\footnotetext{
* 兵庫県立大学大学院生 (Graduate Student, University of Hyogo)
}

り 2), 低減により変形機構が弱化し, 接合面同士が密着しに くくなる.したがって, 接合面の表面粗さを $R_{\mathrm{y}}=0.02 \mu \mathrm{m}$ に仕上げることで低変形接合が達成される報告があるよう に ${ }^{3)}$, 無荷重下での接触面積が重要だと考えられる.

また，拡散接合を始めとする固相接合では，酸化皮膜が金 属結合を阻害し継手強度を低下させる．無酸素銅の場合， 5 $\times 10^{-6} \mathrm{~Pa}$ の超高真空下に㧍いて, $1173 \mathrm{~K}$ で $600 \mathrm{~s}$ の加熱表 面処理を行うことにより酸化皮膜が消失することが報告され ている4 . この消失は, 真空中に抢ける酸素分圧を考慮する と, さらに低真空側でも可能だと思われる.したがって, 表 面処理工程を設けなくとも, 自由表面を保持することにより 昇温中での酸化皮膜の消失が達成できると考えられる.

本研究では, 接合面の表面粗さに加え, あまり考慮されて こなかった接合面同士を接触させる時期に着目し，これらが 継手強度や接合組織に及ぼす影響を調べることにより, 無酸 素銅の低変形固相拡散接合を試みた。

\section{2. 実 験 方 法}

供試材に無酸素銅丸棒 (JIS C1020B) を用い， $\phi 13 \times 30$ $\mathrm{mm}$ に旋盤加工後, 湿式によるエメリ一研磨（\#220, 
\#1000, \# 4000) およびバフ研磨 $\left(\mathrm{Al}_{2} \mathrm{O}_{3}\right.$ : 平均粒径 $\left.0.06 \mu \mathrm{m}\right)$ にて接合面の表面粗さを調整し, 非接触式三次元構造解析顕 微鏡により，接合面の算出平均粗さ $\left(R_{\mathrm{a}}\right)$ を測定した。 その 際, 平行研磨治具を使用することで試料端面間の平行度を損 なわないよう留意した。 また，接合面の清浄化を目的として 一般に行われる酸洗浄の必要性を検証するために，一部の試 料には硝酸: 燐酸 : 酢酸 $=2: 1: 1$ の混合液を用いた $120 \mathrm{~s}$ の化学研磨を実施した. その後, これらの試験片をアセトン 中で超音波洗浄し, 拡散接合に供した.

Fig. 1 に装置の模式図を示す。試料は，処理中に上下駆動 ができるように，一方を上部カーボンロッドに固定した．石 英管内を $4.0 \times 10^{-3} \mathrm{~Pa}$ まで排気した後, 赤外線炉により

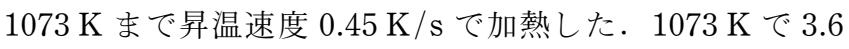
$\mathrm{ks}$ もしくは $7.2 \mathrm{ks}$ 保持した後, $473 \mathrm{~K}$ まで降温速度 0.95 $\mathrm{K} / \mathrm{s}$ で冷却し, 以降室温までは炉冷とした. 圧力は, 油圧プ レスによりカーボンロッドを介して与え，2４ MPa の範囲 で変化させるとともに，接合面の接触ならびに圧力を負荷す る時期を, 従来どおり昇温前に行う場合と接合温度に到達す ると同時に開始する場合の 2 種類において接合を行った.

得られた継手は，接合前後における試料直径の変化により

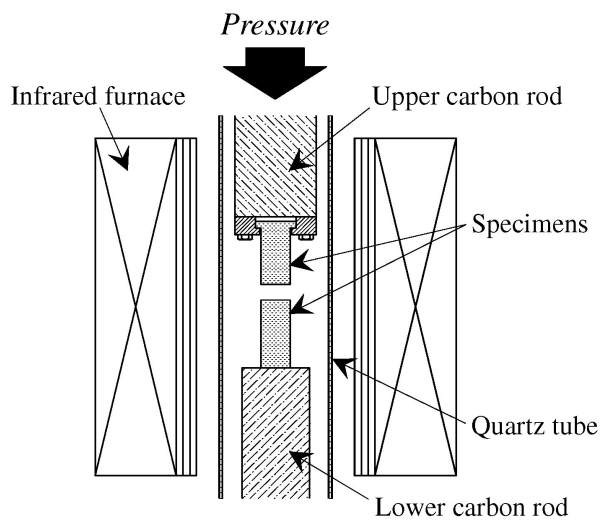

Fig. 1 Schematic illustration for specimen setup.

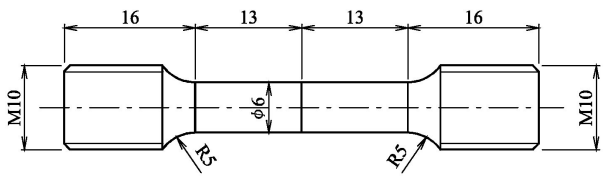

Fig. 2 Shape and dimensions of the specimen for tensile test.
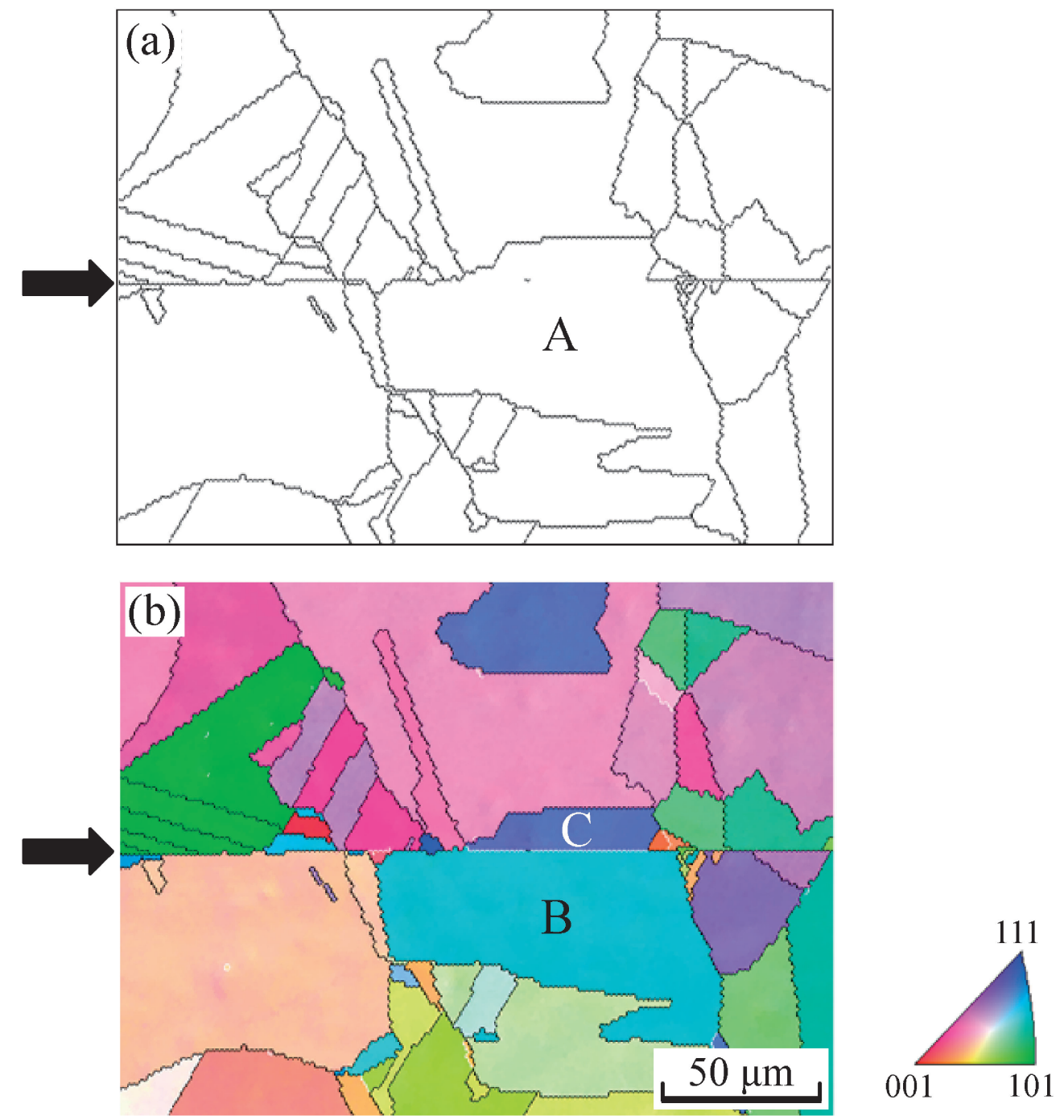

Fig. 3 Microstructures near the bonded interfaces observed by means of SEM-EBSD (a) Blank map and (b) IPF map. The interfaces are indicated by the black arrows. 
変形率を算出した後, Fig. 2 に示すような JIS 4 号の相似試 験片を作製し, クロスヘッド速度 $1.67 \times 10^{-2} \mathrm{~mm} / \mathrm{s}$ で引張 試験を実施した。母材強度は，接合と同様の熱履歴を与えた 材料の破断強度とした. 試験後は, 試料の破断面を SEM (Scanning Electron Microscope)にて観察した.

また，接合部近傍を切り出し，機械研磨および燐酸：エタ ノール $=9: 1$ の溶液を用いた $1 \mathrm{~V} ， 3.6 \mathrm{ks}$ の電界研磨を施 した後, SEM-EBSD (Electron BackScatter Diffraction) 観 察を行った。 EBSDを用いたのは, 界面近傍の組織を詳細 に解析するためである. Fig. 3 にその一例を示す．(a)は方 位差が $15^{\circ}$ 以上の高角粒界のみを示す Blank map であり, 通常の化学エッチングでは $15^{\circ}$ 以下の低角粒界は現出しにく く, 光学顕微鏡観察ではこのような像になると考えられる. (b)は IPF (Inverse Pole Figure) map に，高角粒界および低 角粒界をそれぞれ黒線抢よび白線で示して重ねたものであ る.（a）中の A で示す結晶粒は，接合界面をまたがり成長し ているように見えるが，実際は（b)に示されるように低角粒 界を挟んだ B と C二つの結晶粒である。つまり，界面粒界 移動の有無を正確に判断するためには，低角粒界が観察でき る方法が必要となる.

\section{3. 実験結果および考察}

\section{1 接合圧力と変形率の関係}

$1073 \mathrm{~K} ， 3.6 \mathrm{ks}$ で接合した試料の接合前後における変形 率と接合圧力の関係を Fig. 4 に示す。図中の一点鎖線およ び二点鎖線は，それぞれ一般公差で用いられる JIS B 0405 m(中級) 抢よび JIS B $0405 \mathrm{f}$ (精級)の上限值である. 接合圧 力が $2 \mathrm{MPa}$ の場合では, 寸法変動はあるものの, JIS B $0405 \mathrm{f}$ を十分に満足できる変形率であった。しかしなが ら，適用する圧力が上昇するにつれ変形率は著しく増加し， $4 \mathrm{MPa}$ の場合には変形率が約 $2.5 \%$ となり，一般公差基準は まったく満たせなくなる。無酸素銅の $0.2 \%$ 耐力は 573 , $773,973 \mathrm{~K}$ でそれぞれ $50,28,18 \mathrm{MPa}^{3)}$ である. 本研究で 用いた接合温度は $1073 \mathrm{~K}$ であるため， $0.2 \%$ 耐力は更なる 低下が推測されるが，今回適用した圧力を下回るとは考えに くく, 変形は主としてクリープ変形によるものだと考えられ る. クリープ変形を抑止する上では, 極力低温下での接合が 望ましい。しかし，拡散速度は温度依存性が大きく，継手特 性の低下に繋がる恐れがある。したがって，高温下において 変形を抑制する必要があり，これには接合圧力の低減に加 え，接合時間の短縮が求められる.

一方で，接合面の密着化に対する接合圧力の効果は，2～ $4 \mathrm{MPa}$ の範囲では見られなかった．接合圧力を変化させた 試料に打ける接合界面の SEM 写真を Fig. 5 に示す。これら の試料は，接合前に接合面をエメリー紙＃220にて研磨した もので， $R_{\mathrm{a}}$ 值は $0.765 \mu \mathrm{m}$ であった. 2 $4 \mathrm{MPa}$ の接合圧力 では，凹凸の変形が先端の部分的なものに留まり，接合界面 には比較的大きなボイドが観察され，接合面積の割合を減少 させている，また，ボイドの形状や大きさは接合圧力の違い によって変化せず，いずれの試料に打いても接合界面にはボ イドが残存したままであった。つまり，この範囲の低圧力下

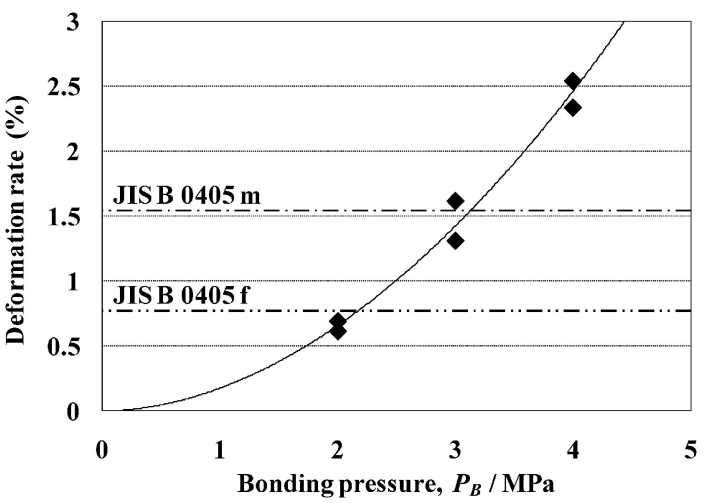

Fig. 4 Relationship between deformation rate and bonding pressure on the specimens bonded at $1073 \mathrm{~K}$ for $3.6 \mathrm{ks}$.
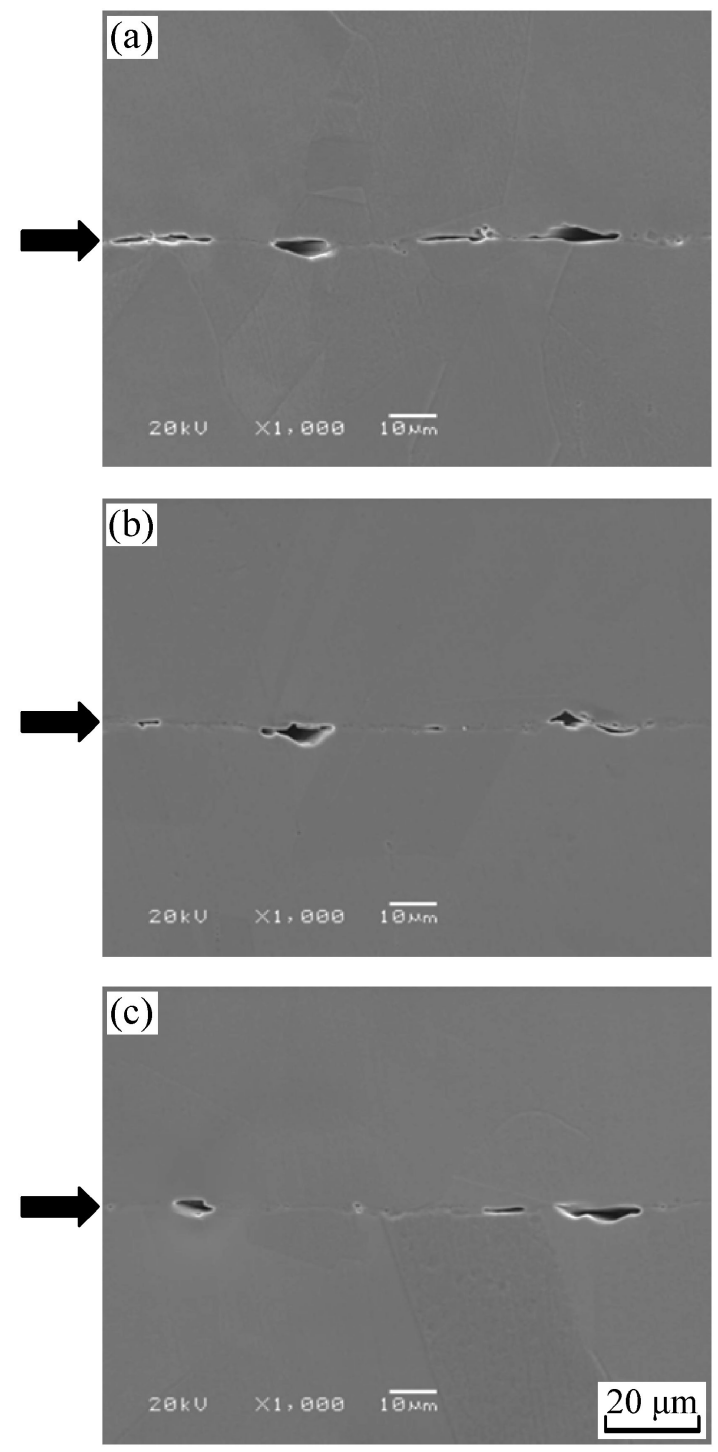

Fig. 5 Bonded interfaces of the specimens fabricated under (a) $2 \mathrm{MPa}$, (b) $3 \mathrm{MPa}$ and (c) $4 \mathrm{MPa}$, respectively. The interfaces are indicated by the black arrows.

では, 接合圧力を増加させたとしても試料全体の変形ばかり が優先し，ボイド収縮に対する圧力の効果はほとんど現れな い.したがって, 密着化を促進するためには, 無荷重下での 接触面積を増加させる必要があり，これには接合面の表面粗 

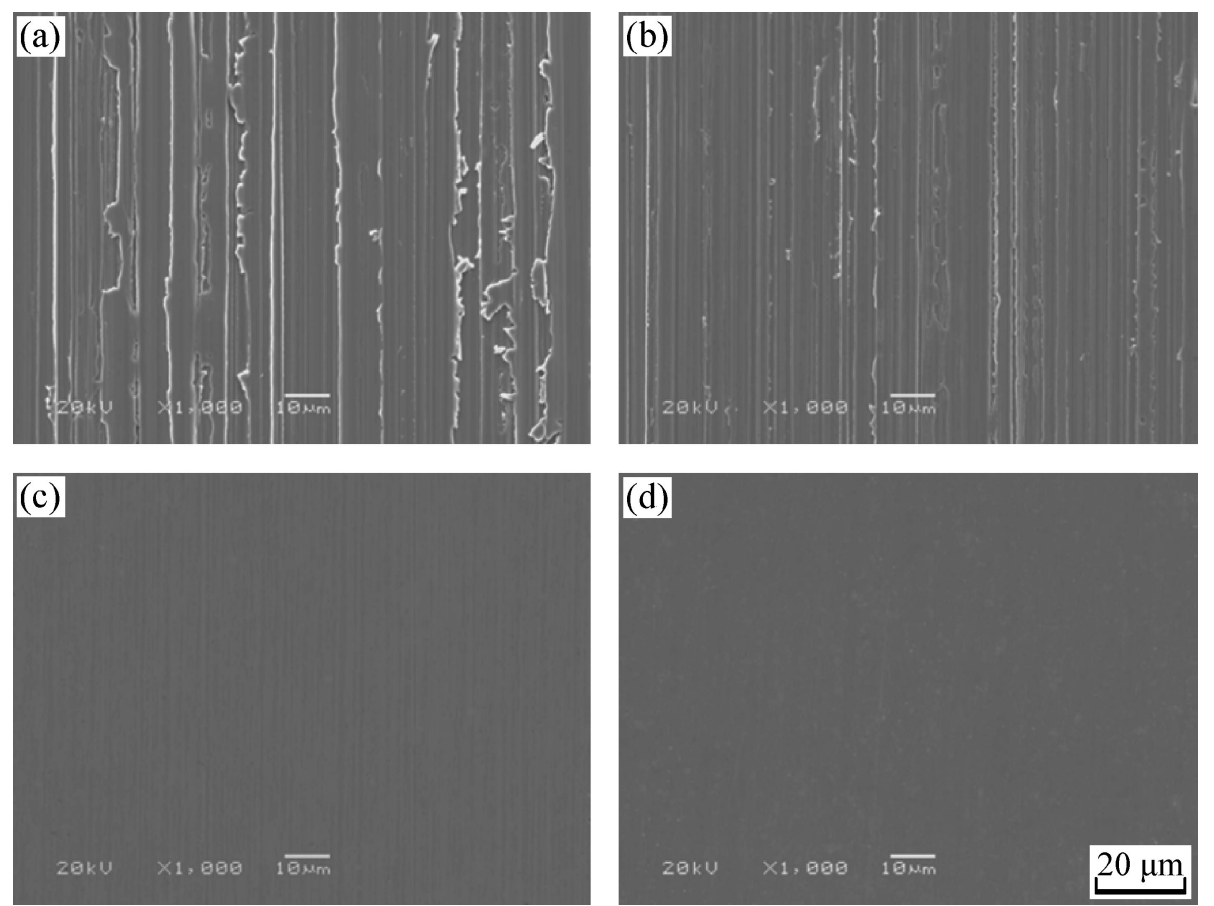

Fig. 6 Morphology of bonding surfaces polished with emery papers and buffing. (a) \#220, (b) \#1000, (c) \#4000, (d) buffing.

\section{さが影響すると考えられる。}

\section{2 継手強度に及ぼす表面粗さの影響}

各研磨により調製した接合面の表面形状を Fig. 6 に示 す. エメリ一紙\#220で研磨した接合面には多数の研磨傷が 観察されるが，\#1000，\#4000へと粒度が小さくなるにつ れ，表面起伏が小さくなり， $R_{\mathrm{a}}$ 值はそれぞれ $0.207,0.061$ $\mu \mathrm{m}$ へ減少した。ささに，バフ研磨した接合面では研磨痕 が除去されて外観的に鏡面を示し， $R_{\mathrm{a}}$ 值は $0.032 \mu \mathrm{m}$ まで減 少した.このように，接合面の表面粗さを変化させた試料に 打ける接合界面の SEM 写真を Fig. 7 に示す。 \#1000 によ り研磨した試料は, \#220で研磨した試料と比較して, ボイ ドの個数は増加する傾向にあったものの，そのサイズは大き く減少した。しかしながら, ボイドは完全消失には至らず, 接合界面に残存したままであった。これに対し，\#4000 打 よびバフ研磨した試料では, 接合界面に明瞭なボイドは観察 されず，接合面積は十分に得られているものと考元られる.

これら接合面の表面粗さを変化させた試料の引張強度を Fig. 8 に示す. \# 220 により接合面を研磨した試料の引張強 度は, 母材強度の約 $50 \%$ であた。. その引張強度は, 接合 面の表面粗さが細かくなるにつれ上昇し， \#4000 およびバ フ研磨した試料では, 母材に匹敵する引張強度が得られた。

\section{しかしながら，いずれの試料も接合界面で破断した.}

拡散接合に抢ける接合面積の増加過程は, 表面の凹凸が塑 性変形抢よびクリープ変形することにより密着化が進行する 变形機構と, 体積拡散や界面拡散によりボイドが収縮する拡 散機構が大きく関与する ${ }^{5)}$. 接合圧力の低減を図った場合, 变形機構の寄与が希薄となり, 接合面積を増加させるには残 る拡散機構の促進が不可欠となる. ボイドの収縮は焼結現象 に類似し, その半径が $2 \mu \mathrm{m}$ 程度に小さくなると収縮速度が
顕著となることが報告されている6 より接合面を調製した試料では, 変形機構に頼らずとも初期 接触時のボイドサイズが既に収縮を加速させるサイズを満た していたために, 拡散機構が促進し, 良好な接合面積ならび に継手強度が得られたと考えられる。

\section{3 継手強度に及ぼす接触夕イミングの影響}

接合温度に到達するまで接合面同士の接触を遅らせた試料 の引張強度を Fig. 9 に示す。接合面をエメリ一紙＃220 お よび\# 1000 により研磨した試料では, 昇温前より接触, 加 圧する従来の方法で接合した場合と比較して引張強度が向上 した. しかしながら, ボイドが残存することにより接合面積 が低下していたため, 破断は接合界面で生じた。 \#4000 お よびバフ研磨された試料に拰てても同様に引張強度は向上し た.さらに，接合界面に明瞭なボイドが観察されず，十分な 接合面積が得られたこれらの試料では, その破断が接合界面 ではなく母材で生じた.

接合面同士の接触, 加圧を接合温度に到達するまで遅らせ た場合, 接触, 加圧された状態にて昇温した場合と比較する と, 厳密には昇温間だけ接合時間が短くなる。そのため, 接 合条件的には不利となるはずであるが，逆により良好な継手 強度が得られている．このことから，接触させるタイミング の違いは, 接合機構に対してではなく, 接合を阻害する因子 に対し効果を奏しているものと推察される。

拡散接合では, 酸化皮膜の安定度が継手特性に大きく影響 する. 無酸素銅の場合, 酸化物は高温, 高真空環境下に扔い て分解が可能である. 無酸素銅の酸化皮膜は, $\mathrm{Cu}_{2} \mathrm{O}$ ならび に $\mathrm{CuO}$ から構成され, 真空排気により酸素分圧を下げた場

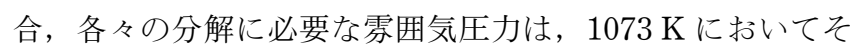
れぞれ $8.3 \times 10^{-2} \mathrm{~Pa}, 68.7 \mathrm{~Pa}$ となる ${ }^{3)}$. 雾团気中の酸素残留 

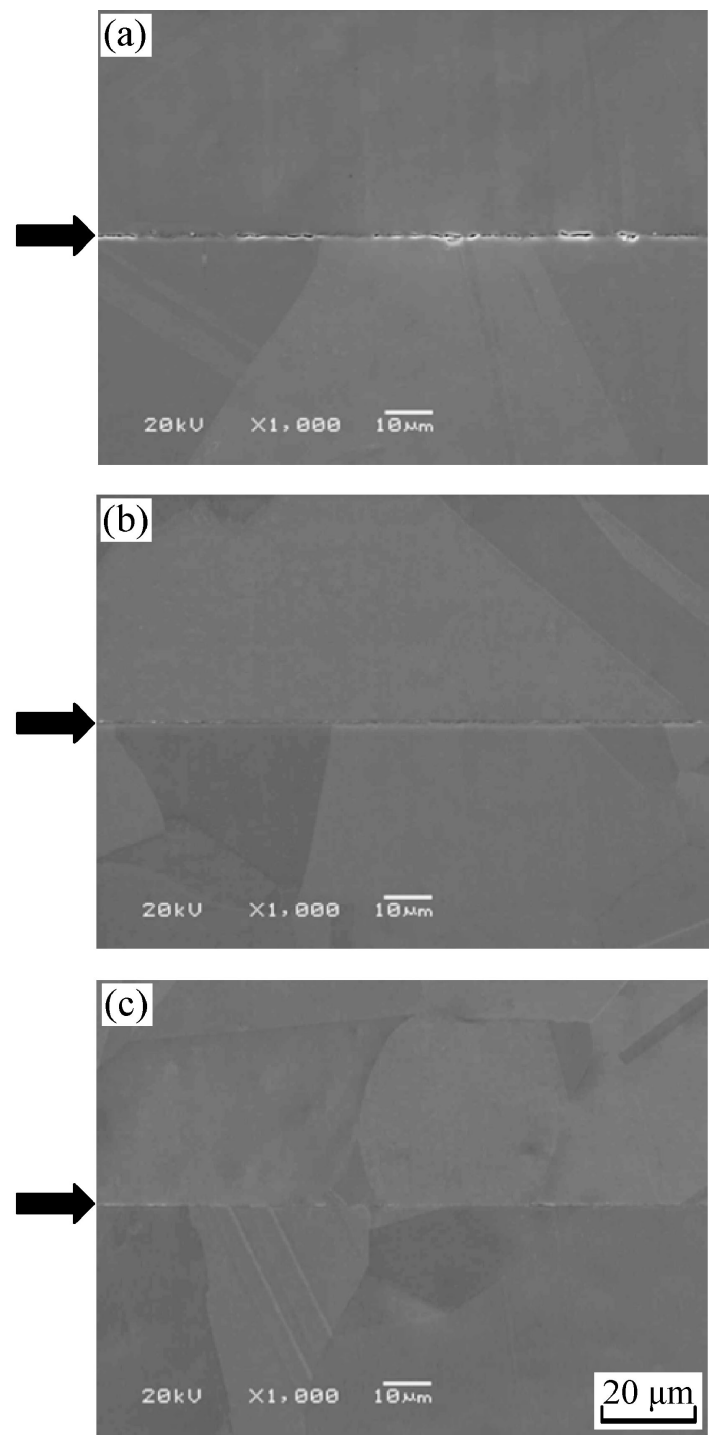

Fig. 7 Bonded interfaces of the specimens prepared by polishing the surfaces with emery papers (a) \#1000, (b) \#4000 and (c) buffing, respectively. The interfaces are indicated by the black arrows.

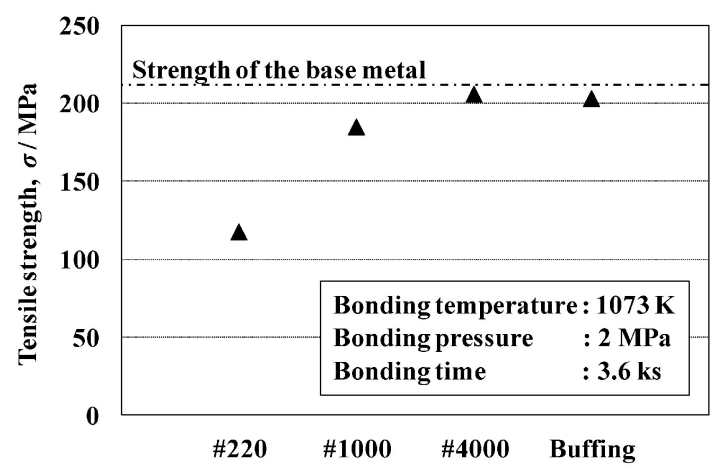

Fig. 8 Relationship between tensile strength and roughness on the bonding surfaces.

量は $0.5 \mathrm{vol} \%{ }^{7)}$ として算出した．本研究の接合雾囲気は，常 に $4 \times 10^{-3} \mathrm{~Pa}$ 以下に保持されて抢り, $\mathrm{Cu}_{2} \mathrm{O}, \mathrm{CuO}$ ともに分 解が起こりうる. しかしながら, 従来の拡散接合では, 接合 面を接触，加圧させた状態で昇温させることが一般的である

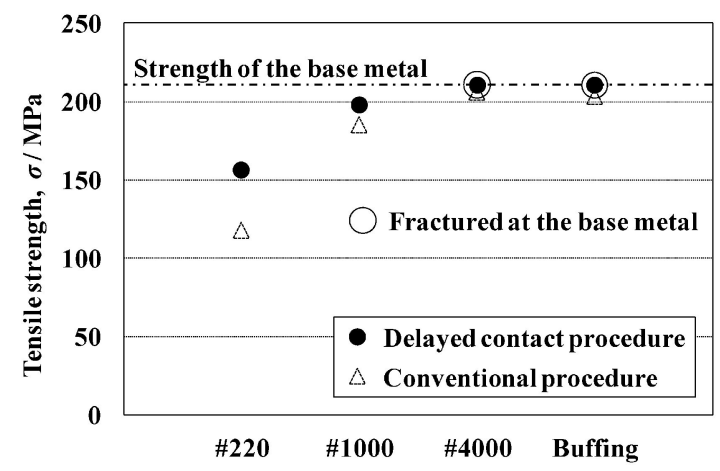

Fig. 9 Tensile strength on the specimens fabricated with the delayed contact procedure. The dashed triangles show the strength indicated in Fig. 8.
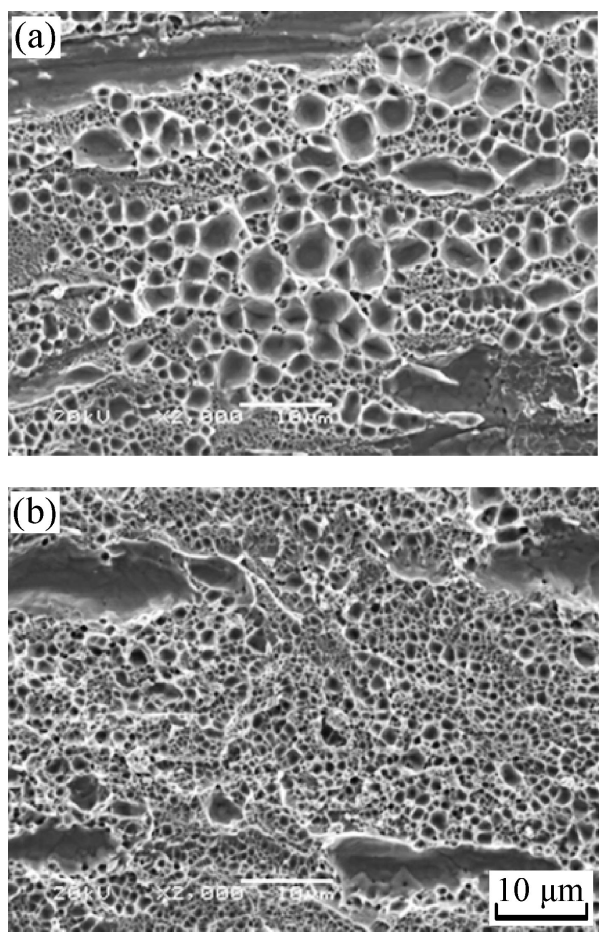

Fig. 10 Fractured surfaces of the specimens fabricated with (a) conventional procedure and (b) the delayed contact procedure, respectively.

ため, 互いの面が接触, 加圧された状態では, 排気状態の悪 化により，接合部近傍の雾囲気圧は増大し，接合部における 酸化物の分解反応は起こりにくいと考えられる.

この接触させるタイミングの違いが及ぼす影響を確認する ために，両者とも界面破断により比較が可能であった，接合 面をエメリ一紙\#220で研磨した試料に抢いて破面観察を行 った．そのSEM 写真を Fig. 10 に示す。研磨痕により接合 面積は低下しているものの, 密着がなされた領域には延性破 壊を示すディンプルが観察された，さらに，昇温前に接合面 の接触, 加圧を行った試料の破面には, 比較的大きなディン プルが諸所で観察された。一方, 接合温度に到達するまで接 合面の接触, 加圧を遅らせた試料の破面においては, これら のディンプルは観察されなかった.

同粒度 (\#220)の研磨紙とはいえ, 研磨紙の粒子状態や手 動による研磨がゆえに, 各々の接合面積には多少なりとも差 
が生じていると思われる. しかしながら，その接合面積の差 は継手強度に影響を及ぼすほど大きなものではなく，ディン プルサイズの違いが歪み速度によって生じたとは考えにくい.

無酸素銅では, 接合面の酸化皮膜が凝縮し, 介在物を形成 する.この介在物は, 接合時間が経過するとともに凝縮が進 行し，母材への酸素拡散により減少するため ${ }^{8)}$, 介在物の減 少度合は母材が持つ酸素固溶限に左右される. 無酸素銅の固 溶量は文献により差があるものの，1073 K で 0.002〜0.009 mass\%である。拡散接合に扔いて酸化皮膜への懸念をほと んど必要としないチタンと比較すると極めて少なく, 接合面 の酸化状態によっては必ずしも母材に含有される既存酸素量 を上回るとは言いがたい。つまり, 酸素の拡散が及ばず減少 割合の小さい介在物が破断起点となったためにディンプルサ イズが大きくなり，これらの介在物が接合界面に多く残留す ることにより，接合界面での破断を誘起したと考えられる.

その反面, 接合温度まで接合面の接触, 加圧を遅らせた試 料の破面では，サイズの大きいディンプルが観察されていな いことから，接合界面にこれらの介在物は存在していなかっ たと思われる. $4 \times 10^{-3} \mathrm{~Pa}$ の雾囲気中で $1073 \mathrm{~K}$ にて接合を 行った際に, 接合界面やボイド表面に存在した介在物は, 自 由表面である材料表面には存在しなかったことが報告されて いる ${ }^{9)}$ ししたがって，接合温度に到達するまで接合面の接触 を遅らせた，すなわち自由表面状態が保持されたことによ り, 昇温中に酸化物の分解反応が進行し, 介在物が消失した ものと考えられる. その結果, 破断起点となりうる介在物が 接合界面には存在しないため, ボイドの消滅により接合面積 が十分に得られた試料では母材破断に至ったと考えられる.

\section{4 酸化皮膜に対する化学研磨の有効性}

機械研磨した後, 接合面に化学研磨を施した試料の引張強 度をFig. 11 に示す。接合面をエメリ一紙＃220で研磨した 試料では，化学研磨を施したことによる引張強度の違いはほ とんど見られなかった。ささらに，機械研磨のみの場合では接 合面の表面粗さが細かくなるにつれ引張強度は向上したが, 機械研磨後に化学研磨を施した場合, \#220 で研磨した試料 とほぼ同值あるいはそれ以下であった.

バフ研磨後, 接合面に化学研磨を施した試料の表面状態お よび引張試験後の破面における SEM 写真を Fig. 12 (a) およ び(b)にそれぞれ示す。バフ研磨により平滑化された試料の 表面では, 化学研磨を施すことにより (a)に示すような段差 が生じる.この段差は, 化学研磨の時間が長くなるにつれ増 大する、段差が生じたことで，窪んだ部分では(b)に示すよ うに接合面同士が密着できなくなり, 接合面積の減少に繋が った. 接合面を＃220で研磨した試料のように，接合面の起 伏が大きく, 化学研磨後もその起伏が残存している場合は, 生じた段差の影響は受けない。しかしながら，バフ研磨した 試料のように，鏡面に比肩する面まで平滑化された場合は， 生じた段差によって表面が粗くなる。ささらに，機械研磨で生 じる凹凸とは違い，段差の形状が急峻でないため変形しにく く，窪んだ部分が密着できずに残りやすい。

また, 破断面の諸所には黒矢印で示すような周囲と比較し てサイズの大きなディンプルが観察される．前述したよう

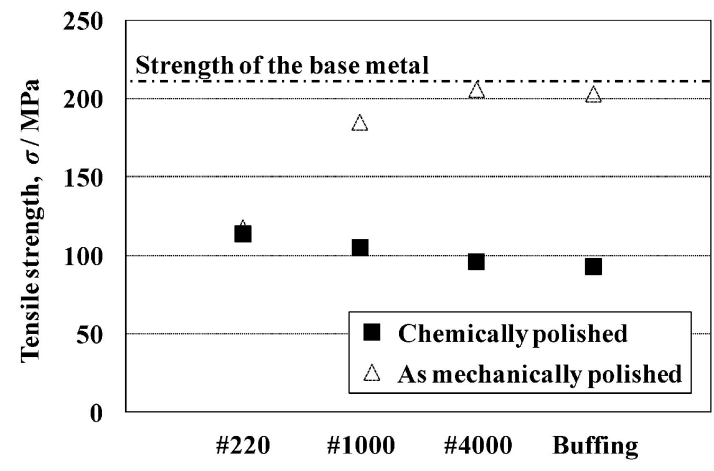

Fig. 11 Tensile strength on the specimens prepared by chemically polishing the surfaces prior to bonding. The dashed triangles show the strength indicated in Fig. 8.
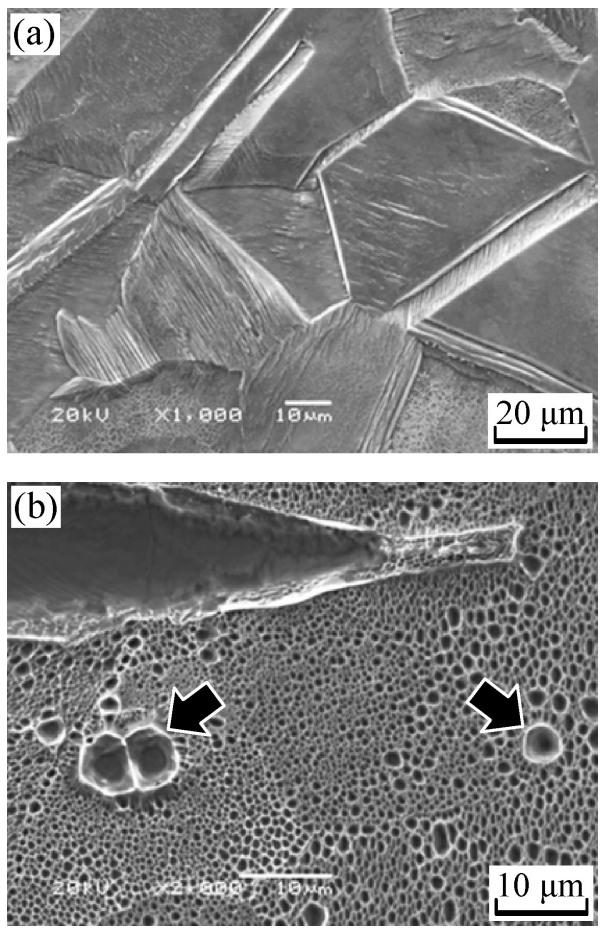

Fig. 12 Morphology of (a) bonding surface and (b) fractured surface on the specimens prepared with buffing followed by chemical polishing, respectively.

に, この場所には酸化皮膜が凝縮し生成された介在物が存在 していたと思われる，つまり，化学研磨を施した後も接合面 には酸化皮膜が存在していたと考えられる，拡散接合では接 合面の清浄度が重要視され, 様々な事前表面処理が実施され ている．しかしながら，無酸素銅は比較的酸化が進行しやす く, 大気に触れることにより再び酸化皮膜が生成される. 接 合面に存在する酸化物の量は, 新生面を表出させた後に接合 面が大気にさらされる時間に関係し，その除去手段が化学的 あるいはエメリー研磨やバフ研磨のような機械的手段であっ ても大差はないと思われる. つまり, 接合面の清浄度を持続 するためには，大気との接触を遮断した状態で接合に臨まな ければならないが，これは容易ではない。化学研磨による接 合面の清浄化には限界があることに加え, 化学研磨によって 生じた段差が接合面積を低下させていることから, 有効性は 極めて低いと考えられる. なお，本研究において，機械研磨 

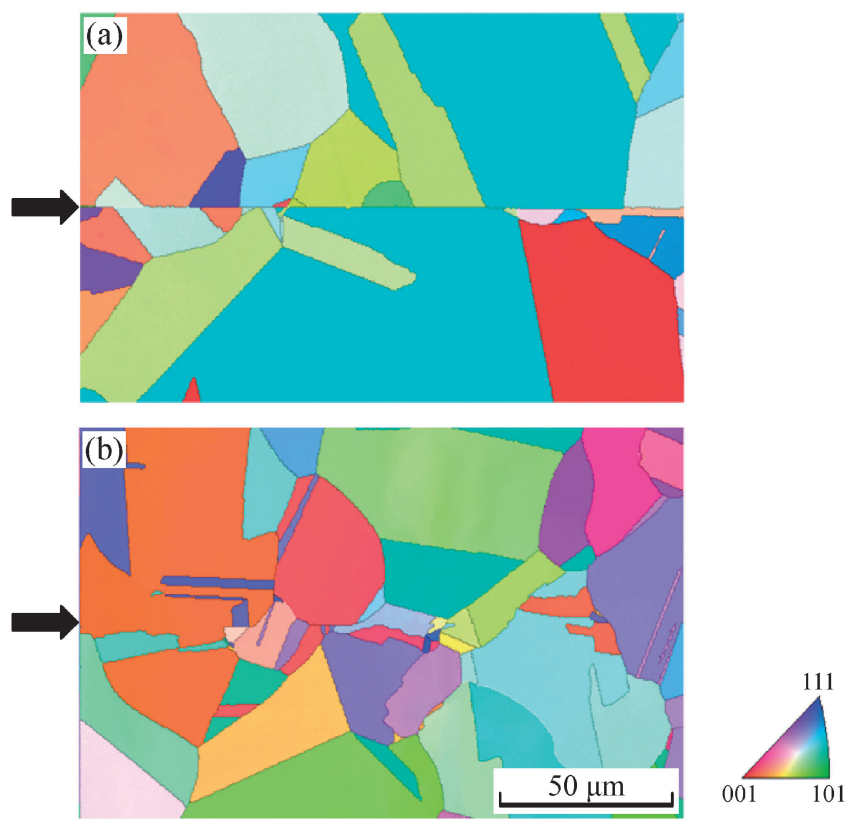

Fig. 13 Microstructures near the bonded interfaces of specimens prepared with buffing. Bonding times are (a) $3.6 \mathrm{ks}$ and (b) $7.2 \mathrm{ks}$, respectively. The interfaces are indicated by the black arrows.

の際に潤滑剤として使用したのは純水であり，切削油等を使 用した場合には，脱脂や変質層などを除去する観点から，化 学研磨の有効性が低いとは言いがたい。

\section{5 接合界面をまたがる結晶粒界移動}

接合面をバフ研磨により調製した試料の接合界面近傍にお ける IPF map を Fig. 13 に示す。接合時間は (a)が $3.6 \mathrm{ks,}$ (b) が $7.2 \mathrm{ks}$ である.（a）に示すように，接合時間が $3.6 \mathrm{ks}$ では結晶粒界が接合界面に沿って存在し，接合界面をまたが る結晶粒はまったく観察されなかった。一方，接合時間を $7.2 \mathrm{ks}$ とした場合には，（b)に示すように，元の接合界面が 特定できないほど結晶粒界の移動が生じていた。この現象が 生じたのは，接合面をバフ研磨した試料の久であり，これ以 外の研磨方法によって調製した試料では，接合時間 $7.2 \mathrm{ks}$ に扔いても結晶粒界が接合界面をまたがって成長しているも のはなく, 接合界面が明瞭に確認できた。 また，接合面を接 触させるタイミングによる違いは, 結晶粒界の挙動には影響 しなかった。

接合界面を観察する前には，ボイドの形状を明瞭にする目 的として電解研磨を施している.この際, 接合部では Fig. 7 に示すように接合界面に沿った窪みが生じる，固相接合面は 一般に結晶粒界として存在することが多く, エッチングは加 速されやすい。しかしながら，その窪み形状は母材内の粒界 と比較すると幅, 深さともに大きく, その性質が異なってい ると考えられる，この寉みは，接合面の表面粗さが細かくな るにつれ，また，接合時間が長くなるにつれ，幅，深さが減 少し, 接合界面をまたがる結晶粒界移動が生じた試料では, まったく観察されなかった。つまり，この寉みが生じる原因 が結晶粒界移動を妨げている要因の一つであると考えられる.

接合界面の粒界が移動を開始するには，接合界面エネル
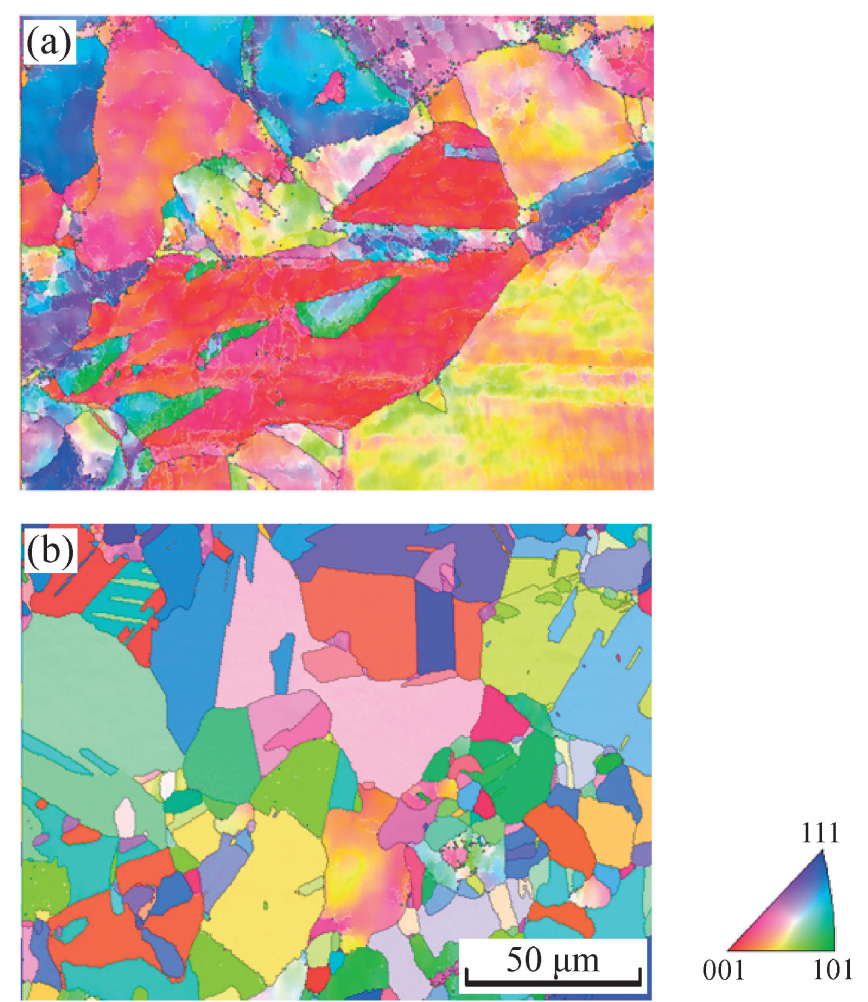

Fig. 14 Changes in microstructures on the specimen coldrolled at $50 \%$ reduction and then annealed at $533 \mathrm{~K}$ for $600 \mathrm{~s}$, (a) before and (b) after annealing, respectively.

ギーが最小になることが指摘され10), さらに, ボイドの存 在が界面エネルギーの低下を遅延させることが報告されてい る11)。前述したように, 拡散機構によるボイドの収縮は, 変形機構とは異なり, 進行にかなりの時間を要する。また, ボイドの初期サイズが小さくなればなるほど，消隇に要する 時間が短縮され，接合界面エネルギーの低下が加速される。 つまり，接合界面に抢ける結晶粒界の挙動には，接合時間な らびに表面粗さが密接に関係すると考えられる.

Fig. 14 に無酸素銅を圧下率 50\%で圧延し， $533 \mathrm{~K}$ で 600 $\mathrm{s}$ 焼鈍した試料の焼鈍前後に抢ける組織变化を示す。(b)に 示すように, $600 \mathrm{~s}$ 後には旧結晶粒界が確認できないほどに 再結晶粒が成長し, 再結晶がほとんど完了している. 無酸素 銅では, 再結晶の進行速度が極めて速く, 拡散接合に扔いて は昇温している段階で再結晶が完了すると思われる。また， 動的再結晶は高圧力が必要であるため, 本研究で適用した低 圧力下では起こり得ない。したがって，接合界面をまたがる 結晶粒界移動は, 主に粒成長 (2 次再結晶) によるものだと考 えられ, その駆動力は歪エネルギーを駆動力とする 1 次再 結晶に比べ, 桁違いに低い12)。そのため, 結晶粒界が接合 界面をまたがり移動するには, より高い温度かつ長い保持時 間が要求される.しかしながら,これはクリープ変形を進行 させることになり, 変形抑制を目的とする上では望ましくな い，一方で，接合面をエメリ一紙＃4000 抢よびバフ研磨に より調製した場合には, 元の接合界面が固着している接合時 間 $3.6 \mathrm{ks}$ の試料に扔いても母材破断に至っている. 接合界 面をまたがる結晶粒界移動は，被接合体同士が一体化したこ とを組織学的に示した証拠ではあるが，継手強度に影響を及 
ぼさないことや被接合体の変形を抑制するという観点から， 必ずしも必要ではないと思われる.

\section{4. 結 言}

接合圧力の低減を助長する条件因子として, 表面粗さなら びに接触タイミングが継手特性に及ぼす影響を調べることに より，高温強度が著しく低下寸る無酸素銅における低変形拡 散接合を試みた。本研究により得られた結果は以下のとおり である。

（1）無酸素銅の機械的強度は，温度上昇とともに著しく低 下し, 接合温度 $1073 \mathrm{~K}$ においては, 接合圧力 $3 \mathrm{MPa}$ 以上 で JIS B 0405 m(中級)を満足する变形率を超過する.

（2）接合圧力 $2 \sim 4 \mathrm{MPa}$ の範囲では，圧力を増加させても 被接合体の変形ばかりが優先され，接合界面に存在するボイ ドの収縮に対して，ほとんど効果を奏さない。

（3）接合面の表面粗さが細かくなるにつれ接合面積は増加 し，エメリー紙＃4000 およびバフ研磨により接合面を調製 した試料では，母材に匹敵する引張強度が得られた。ささ に，接合温度に到達するまで接合面同士の接触，加圧を遅ら せた場合，その破断は接合界面ではなく母材で生じた。

(4) 接合前に化学研磨を行った試料に抢いても，介在物の 存在を示す比較的大きなディンプルが破断面に観察された. また，接合面を平滑にした場合，化学研磨によって生じた段 差が接合面積を低下させた.
（5）接合面をバフ研磨により調製し，接合時間 $7.2 \mathrm{ks} の$ 場合にのみ，接合界面をまたがる顕著な結晶粒界移動が生じ た。一方で，接合時間 $3.6 \mathrm{ks}$ の場合には，元の接合界面が 固着していたにもかかわらず，母材破断を達成した。これに より, 継手強度が結晶粒界移動に依存しないことが示唆され た。

文献

1) A. Wang, O. Ohashi, N. Yamaguchi, Y. Higashi, N. Hitomi and K. Takahashi: Trans. Mater. Res. Soc. Jpn. 27 (2002) 739-742.

2) K. A. Peterson, I. Dutta and M. Chen: J. Mater. Processing Technol. 145(2004) 99-108.

3) Y. Fukaya, Y. Higashi, T. Higo, M. Hamaoka, M. Sueda, T. Kobayashi, M. Ogawa and K. Shinozaki: Quarterly Journal of JWS 15(1997) 467-475.

4) O. Ohashi and Y. Asano: J. Japan Inst. Metals 61(1997) 744749.

5) Y. Takahashi, K. Inoue and K. Nishiguchi: Acta Metall. Mater. 41(1993) 3077-3084.

6) O. Ohashi and T. Hashimoto: Journal of JWS 45(1976) 485491

7) O. Ohashi: Quarterly Journal of JWS 4(1986) 514-520.

8) O. Ohashi, K. Tanuma and T. Kimura: Quarterly Journal of JWS 4 (1986) 53-59.

9) O. Ohashi, K. Tanuma and K. Yoshihara: Quarterly Journal of JWS 3 (1985) 477-483.

10) Y. Ishii: J. Japan Inst. Metals 20(1956) 89-92.

11) T. Hashimoto and K. Tanuma: Journal of JWS 38(1969) 12251233.

12) E. Furubayashi: Saikessyou to zairyososhiki, (Uchida-rokakuho Co. Ltd., Tokyo, 2000) pp. 7-10. 